\title{
FIRMS' EXPORT PERFORMANCE: A FRACTIONAL ECONOMETRIC APPROACH
}

\author{
Samuel FARIA (D) $1,2^{*}$, João REBELO (D)2, Sofia GOUVEIA (D)2 \\ ${ }^{1}$ ISAG - European Business School and Research Group of ISAG (NIDISAG), Porto, Portugal \\ ${ }^{2}$ Department of Economics, Sociology and Management (DESG), \\ Centre for Transdisciplinary Development Studies (CETRAD), \\ University of Trás-os-Montes and Alto Douro (UTAD), Quinta de Prados, \\ 5001-801 Vila Real, Portugal
}

Received 17 December 2018; accepted 13 January 2020

\begin{abstract}
Export activities have become crucial to firms' competitiveness, with determinants of export performance being a challenging field of research, since there is no consensus regarding the explained and explanatory variables or on the econometric methods to be used. Using a panel data of Portuguese wine firms, this paper aims to contribute to this debate, combining both resourceand institutional-based views of the firm. This paper tries to overcome the methodological hurdle, addressing sample selection issues and considering the fractional response nature of export performance. Given the pros and cons of each econometric approach, the Heckman selection model, the fractional probit model and the two-part fractional response model are estimated, and the results compared. From a public policy perspective, the results show that policies that promote wine firm size, labor productivity and wine promotion in third countries have a positive impact on export performance at firm-level. Age does not appear as a key factor on the internationalization of Portuguese wine firms.
\end{abstract}

Keywords: resource-based view, institutional-based view, fractional response variables, sample selection, two-part model, panel data, Portuguese wine industry.

JEL Classification: F14, L25, C23, D22, C24, Q12, C52.

\section{Introduction}

During the last four decades, globalization led to structural changes in most industries, presenting both challenges and opportunities to firms, who need to adapt in order to survive, grow and be competitive in the international market (Mais \& Amal, 2011; Paul et al., 2017). Considering this, export activities have become crucial to firms, as they may boost sales, market power and, consequently, enhance profitability and competitiveness (Chen et al., 2016;

*Corresponding author. E-mails: samuelf@utad.pt; samuelfaria92@hotmail.com 
Maurel, 2009; Paul et al., 2017). Therefore, research has been focused on explaining firms' export performance, its determinants and how exports relate to firm performance (Chen et al., 2016; Sousa et al., 2008).

Export performance is typically analysed through export intensity, a ratio between export sales and total sales, thus assuming values in the interval $[0,1]$, which expresses two firm strategic decisions. First, the decision of whether to be present in external markets, i.e. export propensity, measured by the dichotomous variable 0 or 1 . Then, the second decision, how much to export, measured by the export intensity continuous variable [0,1]. Neither strategic decisions are dissociable, since firms do not decide whether to export and how much to export separately: indeed, the decision to export is usually followed by purchase orders or customer requests.

Although the research into firms' export performance is widely spread, with different explained variables and methodologies used, there is no convergence either in the results or in the econometric methods to be used to address this issue (Chen et al., 2016), suggesting additional research. Therefore, this paper aims to contribute to this debate, providing results supported on robust approach and that can be useful for public policy and also for firm managers. The choice of performing export at the firm level in detriment of "average" or macroeconomic aggregates in is line with the literature that favors the use of micro-data for deriving more robust estimators basing policy making (EC, 2014), given the heterogeneity of performance between industries and within firms in the same industry. The econometric tools also be fit well the "production technology" assumed as well as the correspondent data.

Therefore, the innovation of this paper is focused on the application of new econometric approaches in order to contribute to a better understanding of export performance, providing unbiased and reliable insights.

Export performance is analysed from a combined resource-based view (RBV) and institutional-based view (IBV), and sample selection issues are addressed considering the fractional nature of the dependent variable. Thus, using data from the Portuguese wine industry, this paper applies (i) a two-step Heckman selection model, (ii) a fractional probit model and (iii) a two-part fractional response model, including the analysis of the pros and cons of each approach and interpreting and comparing the results.

The wine industry offers a solid example of a true global market, encompassing most features of a monopolistic competition structure, namely (i) the existence of a large number of firms with limited control over price-output; (ii) product heterogeneity; (iii) asymmetric information; and (iv) freedom to enter or exit the market (D’Aspremont et al., 1996; Parenti et al., 2017). Within the wine industry, both supply and demand sides have changed significantly worldwide. The supply side has registered increased competition, due to the entrance and rapid growth of new entrants in the market, the so-called 'New World' producers (Menghini, 2015). On the demand side, new substitute products and lifestyle changes have led to an overall decrease in consumption of Old World wine, compensated by the increase of consumption in emerging and new markets (Hammervoll et al., 2014; Menghini, 2015).

In order to achieve the main goal, besides this introduction the paper is organized as follows: section 1 provides an overview of the literature regarding export performance; section 2 presents and explains the econometric approaches used; section 3 presents data and results. The last section sets out the main conclusions and policy implications of the findings. 


\section{Literature review}

Using the theory of the firm, the relationship between exporting activities and firm performance has been the object of a wide number of studies by scholars and researchers. Chen et al. (2016) state the resource-based view (RBV), the institutional-based view (IBV), the contingency theory (CT) and the organizational learning theory (OLT) as being the most prominent perspectives to explain this relationship.

The RBV is the most widely used theory in this field, stating that firms operate over a unique set of resources, tangible or intangible, and that these internal and controllable resources determine firms' performance (Barney et al., 2001; Chen et al., 2016; Helfat \& Peteraf, 2003; Wernerfelt, 1984). Thus, the RBV suggests that disparities in export performance derive from competitive advantages (or disadvantages) determined by each firm set of internal resources (Barney, 1991; Lorenzo et al., 2018). Although firms' resources might play a crucial part explaining competitive advantages and export performance, it seems reasonable that it is also influenced by both market dynamics and institutional environment (Mais \& Amal, 2011; Peng et al., 2008).

The IBV focuses on the institutional factors, suggesting that the institutional environment faced by firms acts as a moderating effect, shaping firms' strategic decisions, and therefore export behaviour, consequently determining firms' export performance (Mais \& Amal, 2011; Peng et al., 2008; Sousa et al., 2008).

The CT, on the other hand, highlights the importance of context compatibility regarding firms' strategic decisions. This approach states that the performance of exporting firms depends on how firms can co-align their internal resources/capabilities with the institutional environment (Harrigan, 1983; Hultman et al., 2011). Thus, depending on the environmental contexts, the same strategies may result in different export performances (Robertson \& Chetty, 2000). Finally, the OLT refers to the importance of the learning effects on strategic decisions, i.e. organizations learn from past activities/decisions, which improve their knowledge on strategies and surrounding conditions, thus having a moderating effect on future activities (Santos-Vijande et al., 2012).

According to Chen et al. (2016), the strategic decisions regarding exports are mainly based on the firms' resources, management characteristics and external forces. The collusion of these factors directly influences export performance, its determinants being explained by combining both firm-level resources and country-level institutions, i.e. the RBV and the IBV perspectives.

Regarding applied research on export performance, most papers focus on two main moments of export strategic decision, specifically export propensity (usually measured with a binary variable) and export intensity (fractional variable) as dependent or explained variables (Antonietti \& Marzucchi, 2014; Anwar \& Nguyen, 2011; Behmiri et al., 2019; Fernández \& Nieto, 2006; Ganotakis \& Love, 2012; Lee et al., 2009; Lu et al., 2009; Singh, 2009; Wang et al., 2017, 2013; Yi et al., 2013). Table A1 in Appendix includes an overview of these studies, including authors, theoretical perspective (RBV or IBV), explanatory variables, econometric method and main results.

With regard to the internal characteristics and resources in most of the studies, firm size and export experience (Chen et al., 2016; Fan et al., 2019; Sousa et al., 2008) are usually iden- 
tified as positive determinants of export performance. The main support for this result is that larger, experienced firms have more available resources, taking advantage of scale economies and benefiting from higher market power (Chen et al., 2016).

Other studies (Lee et al., 2009; Wang et al., 2013) focus on the effects of firm individual capabilities, such as research and development (R\&D) or technological orientation on export performance, finding positive links between these capabilities and export intensity. Onkelinx et al. (2016) argue that labour productivity and investments in human capital are crucial to Small and Medium-sized Enterprises (SMEs) internationalization success. Brakman et al. (2019) mentioned the importance of productivity and internal characteristics regarding the decision to export. Lopez-Rodriguez et al. (2018) also state that advanced training and skilled workers can improve firms' export performance. Fernández and Nieto (2006) analysed the type of ownership, finding evidence that family-owned firms are less likely to export. Firms' financial situation is also usually stressed as an important issue to firms' performance and consequently, definition of strategies. Firms' capital structure is another internal factor driving economic performance, and consequently firms' strategy regarding approaching external markets (Burgman, 1996; Delen et al., 2013; Gonenc \& de Haan, 2014; Le \& Phan, 2017). Although there is no consensus on how capital structure influences export performance, Gonenc and de Haan (2014) refer to the impacts of leverage, as Delen et al. (2013) state that net profit margin is one of the most important indicators to assess overall firm performance.

The IBV perspective is also stressed in applied research. Several papers studied the effects of different institutional environments on export propensity and intensity. Anwar and Nguyen (2011) found that foreign direct investment in the home country impacts firms' decision to export. On the other hand, Yi et al. (2013) argue that the institutional environment has a moderating effect on exporting activities, following the same line with $\mathrm{Lu}$ et al. (2009), who stated that export intensity is higher when the institutional environment is conducive. Other studies focused on how institutions may shape firms' export performance. Wang et al. (2017) analysed the effects of export promotion programmes, namely financial-aid programmes, and found that these have an enhancing power, helping firms to boost their export performance. Simmilarly, Malca et al. (2019) stressed that experience from export promotion programmes positively impacts SMEs export propensity and overall export performance. These findings are corroborated by other authors (De Falco \& Simoni, 2014; Leonidou, 2004; Munch \& Schaur, 2018).

Regarding the econometric methods used, there is a fragmentation, depending on the type of the dependent/explained variable used. While some authors separate export propensity from export intensity (Fernández \& Nieto, 2006; Munch \& Schaur, 2018), others focus on models for censored variables (Lopez-Rodriguez et al., 2018; Lu et al., 2009; Wang et al., 2013) when trying to explain export performance. Sample selection issues are also addressed (Krammer et al., 2018; LiPuma et al., 2013). The divergence of results according to the approach used seems to demand more empirical research, the application of new econometric approaches remaining a challenge when analysing export performance (Chen et al., 2016). 


\section{Econometric approach}

In applied research (see Table A1 in Appendix A), export performance is usually measured as the share of export sales on total turnover (Chen et al., 2016). Thus, emerges a fractional response variable, filling the condition $0 \leq y \leq 1$, whereas a value of $y=0$ represents nonexporters. Therefore, considering $\theta$, a vector $x$ of $k$ covariates, which are to explain the dependent variable, the focus is on estimating the mean response of $y$, thus estimating $E(y \mid x)$. Consequently, the linear specification $E(y \mid x)=x \theta$ becomes inconsistent, since it assumes a linear effect of explanatory variables on the predicted value of $y$, which can drive predicted values outside the boundaries $[0,1]$, and may produce meaningless outcomes, with no valid interpretation, including of the marginal effects.

As referred by Chen et al. (2016), several studies separate export propensity and export intensity as variables of interest, modelling export propensity as the decision to export and export intensity as the decision on how much to export. However, modelling export intensity considering only firms who export may induce sample selection bias. Heckman (1979), in his seminal paper, stated that sample selectivity occurs when the selection into the observed sample is not random. Thus, excluding non-exporters and estimating export intensity with exporters only, may induce selectivity bias. In order to correct this sample selection bias, Heckman (1979) proposed the sample selection model, defined by

$$
\begin{gathered}
y_{i}^{*}=x_{i}^{\prime} \beta+u_{i} ; \\
z_{i}=1\left(w_{i}^{\prime} \gamma+\varepsilon_{i}>0\right) ; \\
y_{i}=z_{i} y_{i}^{*},
\end{gathered}
$$

where $x_{i}^{\prime}$ denotes the independent observed variables ${ }^{1}$ influencing the latent outcome $y_{i}^{*}$, and $u_{i}$ defines the error term in the regression Eq. (1). $z_{i}$ is the selection equation, in this research an observed binary variable indicating whether a firm is exporting $\left(z_{i}=1\right)$ or not $\left(z_{i}=0\right)$, with explanatory variables given by $w_{i}^{\prime}$, whereas $\varepsilon_{i}$ is the error term of the selection Eq. (2). Therefore, $y_{i}$ is observed when $z_{i}>0$, as in Eq. (3). In this model, both $u_{i}$ and $\varepsilon_{i}$ capture the aggregated effects of the unobserved terms and are assumed to follow a conditional bivariate normal distribution, expressed by

$$
\left(\begin{array}{l}
u_{i} \\
\varepsilon_{i}
\end{array}\right) \mid x_{i}, w_{i} \sim N\left(\left(\begin{array}{l}
0 \\
0
\end{array}\right),\left(\begin{array}{cc}
\sigma_{u}^{2} & \rho \\
\rho & 1
\end{array}\right)\right) \text {, }
$$

where $\rho$ is the correlation coefficient between $u_{i}$ and $\varepsilon_{i}$. Thus, when $\rho \neq 0$, the estimation might suffer from sample selection bias. To overcome bias, the Heckman selection model

\footnotetext{
${ }^{1}$ In a two-step procedure, it is recommended to include an additional explanatory variable in the selection equation. In this paper, net profit is used. Delen et al. (2013) refer to the importance of net profit margins to firms' profitability and consequently, strategic decisions. Additionally, other authors (Nam et al., 2018) also used profitability measures in two-step Heckman estimates, finding a negative relation between them and export propensity in the selection equation.
} 
calculates and introduces the inverse Mills' ratio $^{2}$ into the regression equation, allowing for unbiased results.

The main drawback of the Heckman sample selection model is that since the regression equation (Eq. (1)) assumes a linear relationship between the regressors and the dependent variable, consequently, it may produce predictions outside the meaningful $[0,1]$ interval. Additionally, the Heckman selection model requires normality to hold. Moreover, the model does not solve for neglected heterogeneity, making the interpretation not straightforward. The sample selection model also requires the specification of an exclusion restriction, i.e., a selection equation that includes a regressor that is exogenous to the main equation. This procedure allows the normality assumption to hold, as it acts as an instrumental variable, correcting possible bias arising from applying the Inverse Mill's ratio to endogenous covariates.

In order to overcome this drawback, a fractional response variable ought to be estimated through an alternative econometric approach, ensuring that $E(y \mid x)$ lies on the meaningful interval $[0,1]$, and that the estimation produces consistent and unbiased results.

Tobit models are often used as an alternative approach (Lopez-Rodriguez et al., 2018; Lu et al., 2009; Wang et al., 2013), but they usually are used when there are observations in both limits of the interval $[0,1]$, which is rarely the case. In addition, observations in the boundaries represent individual choices and strategies, not censoring (Ramalho et al., 2011). Furthermore, Tobit models requires normality and homoscedasticity of the dependent variable to hold.

Papke and Wooldridge (1996), in their seminal paper, proposed another solution, through the estimation of

$$
E\left(y_{i} \mid x_{i}\right)=G\left(x_{i} \theta\right)
$$

where $G(\bullet)$ is a known function satisfying $0 \leq G(z) \leq 1$ for all $z \in \mathbb{R}$, thus ensuring the predicted values of $y$ lie in the $[0,1]$ interval. In applied research, two main solutions for $G(\bullet)$, as a cdf, are typically used, namely the logistic function, $E(y \mid x)=\frac{e^{x \theta}}{1+e^{x \theta}}$, (fractional logit) and the standard normal distribution function, $E(x \mid y)=\Phi(x \theta)$ (fractional probit), which ought to be estimated through non-linear techniques.

The quasi-maximum likelihood (QML) method is suggested to estimate $\theta$ in Eq. (5), given by

$$
\hat{\theta}=\arg \max \theta \sum_{i=1}^{N} \operatorname{LLi}(\theta) \text {. }
$$

This QML method is based on the Bernoulli log-likelihood function, which is defined by

$$
L L i(\theta)=y_{i} \log \left[G\left(x_{i} \theta\right)\right]+\left(1-y_{i}\right) \log \left[1-G\left(x_{i} \theta\right)\right] \text {. }
$$

\footnotetext{
${ }^{2}$ The inverse Mill's ratio, named after John P. Mills, is the ratio of the probability density function over the cumulative distribution function, which is given by $\lambda_{i}=\frac{\phi\left(z_{i}^{\prime} \gamma\right)}{\Phi\left(z_{i}^{\prime} \gamma\right)}$, where $\phi$ denotes the standard normal density function (pdf) and $\Phi$ denotes the standard normal cumulative distribution function (cdf).
} 
Papke and Wooldridge (2008) developed the panel data extension of this model, given by

$$
E\left(y_{i t} \mid x_{i t}, \alpha_{i}\right)=\Phi\left(x_{i t} \beta+\alpha_{i}\right), \quad t=1, \ldots, T,
$$

which allows to capture the effects of neglected heterogeneity. This non-linear approach allows the estimation of Eq. (5), producing meaningful and consistent results.

However, since the (non-linear) estimation of the conditional mean, through fractional logit or fractional probit models, only apply well when few observations are in the boundary levels. Ramalho et al. (2011) argue that when the number of boundary observations is large, two-part models are often a superior solution. Moreover, the use of two-part models solves sample selectivity issues by estimating separately the binary and continuous components of the dependent variable. In two-part models, the discrete component is estimated through a binary model (the first part), while the continuous component, is estimated as a fractional regression model (second part).

Thus, following Ramalho et al. (2011) the first part of this model is defined by a standard binary choice model, modelling the probability of observing a positive outcome,

$$
\begin{gathered}
y^{*}= \begin{cases}0, & y=0 \\
1, & y \in(0,1)\end{cases} \\
P\left(y^{*}=1 \mid x\right)=E\left(y^{*} \mid x\right)=F\left(x \beta_{1 P}\right),
\end{gathered}
$$

where $F(\bullet)$ is the distribution function, usually the logistic function or the standard normal. In export behaviour, this models the probability of exporting, i.e. export propensity.

The second part of this model considers only the positive outcomes in Eq. (8) and models the magnitude of non-zero outcomes. In export behaviour, this means taking exporters only and modelling export intensity. The second part may be defined by

$$
E\left[(y \mid x, y \in(0,1)]=M\left(x \beta_{2 P}\right),\right.
$$

where $M\left(x \beta_{2 P}\right)$ may be estimated through the QML method. Considering Eqs. (10) and (11), and following Ramalho et al. (2011) $E(y \mid x)$ is defined by

$$
E(y \mid x)=E\left[(y \mid x, y \in(0,1)] \times P[y \in(0,1) \mid x]=M\left(x \beta_{2 P}\right) \times F\left(x \beta_{1 P}\right) .\right.
$$

Considering the fractional response nature of the variable of interest, the quantity of boundary observations, as well as the sample selectivity issues, this two-part model approach produces meaningful and consistent results.

Regarding the economic interpretation of the estimations, it is important to point out that the focus of the three approaches is on estimating $E\left(y_{i} \mid x_{i}\right)$, which leads to computing and understanding the partial effects of the regressors on the expected value of the dependent variable. The average marginal effects (MEs) in the Heckman selection model (Saha et al., 1997) are given by

$$
M E_{X_{k}}=\frac{\delta E\left[y_{i} \mid z_{i}^{*}>0\right]}{\delta X_{k}}=\beta_{k}-\gamma_{k}\left(\rho \sigma_{j}\right) \delta_{i}\left(\alpha_{u}\right),
$$


where $X_{k}$ denotes the vector of regressors; $\beta$ the associated parameters and considering that $\lambda\left(\alpha_{u}\right)$ refers to the parameter of the inverse Mills ratio (therefore meaning $\left(\alpha_{u}\right)=-w_{i}^{\prime} \gamma$ ). In the fractional probit of Papke and Wooldridge (2008) the average MEs for continuous $X_{j}$ are given by

$$
M E_{X_{k}}=\frac{\delta E\left[y_{i t} \mid X_{i t}, \alpha_{i}\right]}{\delta X_{k}}=\beta_{k} \phi\left(X_{i t} \beta+\alpha_{i}\right),
$$

where $\phi$ denotes the standard normal conditional distribution function. In the two-part model for fractional response variable, the average MEs are given by

$$
M E_{X_{k}}=\frac{\delta E\left(y_{i} \mid x_{i}\right)}{\delta X_{k}}=\frac{\delta M\left(x_{i} \beta_{2 P}\right)}{\delta X_{k}} F\left(x_{i} \beta_{1 P}\right)+\frac{\delta F\left(x_{i} \beta_{1 P}\right)}{\delta X_{k}} M\left(x_{i} \beta_{2 P}\right) \text {. }
$$

The average MEs for dichotomous explanatory variables are given by the difference of the adjusted predictions,

$$
M E_{X_{k}}=\delta E\left(y_{i} \mid x_{i}\right)=\operatorname{Pr}\left[y_{i} \mid x_{i k}=1\right]-\operatorname{Pr}\left[y_{i} \mid x_{i k}=0\right]
$$

Summarizing, each econometric approach seems to present both pros and cons. Therefore, in order to analyse the robustness of the results, the use of different econometric approaches seems to be desirable.

\section{Data and results}

\subsection{Data}

As referred in the introduction, in this paper, firms' export performance is analysed using data on the Portuguese wine industry. Considering the firms operating in this market may be divided into (i) grape-growers, who produce and sell grapes; (ii) merchants, i.e., firms selling wine, without producing; (iii) producers, i.e., those firms who produce and sell wines. Considering technological homogeneity of the sample, this paper includes only firms in the third category. The data sources are the official fiscal reports (Informação Empresarial Simplificada - IES) of Portuguese firms that produce still and liquor wines, included in the 11021 NACE (statistical classification of economic activities of the EU or Nomenclature statistique des activités économiques dans la Communauté Européenne) for the years 2014, 2015 and 2016.

After a screening, with data availability from all variables at all time points as the main selection criteria, the final sample consisted of a balanced panel of 412 wine-producing firms from all over the country. Therefore, the sample comprised 1236 observations, covering a 3-year period.

Based on the literature review presented in section 2, the RBV variables included in the econometric analysis are firm size, firm age, labour productivity and debt capacity ratio. In order to also incorporate the IBV perspective, a dummy variable was added to control for the benefits of public funding and the country-wide level of exports, control- 
ling for the dynamics of export activity. It is important to notice that the included variables are result of a random sample. Table 1 includes the list of variables used, their role and their definitions.

Table 1. List of variables

\begin{tabular}{|c|l|}
\hline \multicolumn{1}{|c|}{ Role/Variable } & \multicolumn{1}{c|}{ Definition/Computation } \\
\hline Dependent Variable & \\
\hline Export Performance & Export turnover / Total turnover \\
\hline Explanatory Variables & \\
\hline Size & Total turnover \\
\hline Age & Years since foundation \\
\hline Productivity & Gross value added / number of employees \\
\hline Beneficiary & $\begin{array}{l}\text { Dummy variable (1 if firm benefits from public funding for promotion } \\
\text { in third countries; 0 otherwise) }\end{array}$ \\
\hline Control Variables & \\
\hline Debt Capacity & Equity / (Equity + Long-term debt) \\
\hline Exports PT & Total exports of goods and services (Portugal) \\
\hline Selection Variable & \\
\hline Net Profit & Net profit (or loss) for the year. \\
\hline
\end{tabular}

Table 2 displays the descriptive statistics for the whole data sample. It is noticeable that in all three years analysed, exporter firms outnumber non-exporters, meaning that the Portuguese wine industry is, generically, an exporter industry. Moreover, nearly $60 \%$ of the firms are exporters, with an average export intensity of $17.8 \%$. The mean value for firm turnover (size) was $2,425,462 €$. The average firm age of this sample is 21 years, with the youngest being 3 years old and the oldest firm 117 years old. Regarding productivity, the average input per employee, in terms of gross value added, is $32,273.27 €$. With regard to firms' financial situation, debt capacity is a long-term indebtedness indicator. It varies from 0 to $100 \%$, with 0 suggesting that firms' have exhausted their borrowing power, and $100 \%$ meaning it is fully available. Thus, in this sample, the mean is nearly 59\%, which indicates a solid financial situation across the sample. The dummy 'beneficiary' shows which firms have benefited from public funds regarding promotion in third countries, thus evaluating public policies regarding promotion of exports. In this sample, nearly $16 \%$ of firms have, in any moment, benefited from any public fund to promote in third countries.

The variable 'exports PT', i.e. the total of Portuguese exports, is considered in order to assess the impact of the country-wide exporting dynamic in firms' export performance. In the period analysed, Portugal's exports grew by $10.84 \%$, which means an average annual rate of $5.3 \%$ and implies a positive dynamic in the period under analysis.

Net profit, a sample selection variable used to solve econometric issues in the two-step Heckman selection model, has an average of 170,709 euro, with a large spectrum between a minimum of $-1,568,700$ euro and a maximum of $13,175,734$ euro. 
Table 2. Descriptive statistics for whole sample $(\mathrm{N}=412 ; \mathrm{T}=3)$

\begin{tabular}{|l|l|c|c|c|c|c|}
\hline \multicolumn{1}{|c|}{ Variable } & \multicolumn{1}{|c|}{ Unit } & Obs & Mean & Std. Dev. & Min & Max \\
\hline $\begin{array}{l}\text { Export } \\
\text { Performance }\end{array}$ & Ratio & 1236 & 0.1789 & 0.2593 & 0 & 1 \\
\hline Size & $10^{5}$ Euro & 1236 & 24.2546 & 94.61606 & 0.0023 & 1378.8245 \\
\hline Age & Number & 1236 & 21.2233 & 19.8366 & 3 & 117 \\
\hline Productivity & $10^{4}$ Euro & 1236 & 3.2273 & 8.5230 & -131.4014 & 191.1506 \\
\hline Debt Capacity & Ratio & 1236 & 0.5881 & 0.3501 & 0 & 1 \\
\hline Beneficiary & Ratio & 1236 & 0.1626 & 0.3692 & 0 & 1 \\
\hline Exports PT & $10^{6}$ Euro & 1236 & $70,166.1545$ & $3,609.004$ & $66,408.6140$ & $73,605.5579$ \\
\hline Net Profit & Euro & 1236 & $170,709.2$ & $1,047,056$ & $-1,585,700$ & $13,175,734$ \\
\hline $\begin{array}{l}\text { Export } \\
\text { Propensity }\end{array}$ & Dummy & 1236 & 0.59627 & 0.49084 & 0 & 1 \\
\hline
\end{tabular}

In order to verify the possible existence of collinearity between explanatory variables, the variance inflation factor (VIF) statistic was calculated. By rule of thumb, 10 takes on a critical value for the presence of multicollinearity, thus, as presented in Table 3, the presence of multicollinearity can be dismissed.

Table 3. Variance inflation factor (VIF) statistics of explanatory variables

\begin{tabular}{|l|c|c|}
\hline \multicolumn{1}{|c|}{ Variable } & VIF & 1/VIF \\
\hline Beneficiary & 1.25 & 0.797563 \\
\hline Size & 1.21 & 0.829160 \\
\hline Age & 1.20 & 0.836059 \\
\hline Productivity & 1.08 & 0.927232 \\
\hline Debt Capacity & 1.07 & 0.932579 \\
\hline Exports PT & 1.00 & 0.998042 \\
\hline
\end{tabular}

The linear relationships between pairs of explanatory variables are also addressed through the Pearson correlation values. Thus, Table 4 displays the pairwise Pearson correlation matrix. $^{3}$ It is worth noting the only-positive nature of the correlations, as well as their small magnitudes, implying that it is not advisable to exclude any of the variables considered.

Taking into consideration the methods described in sections 2 and 3, the econometric approach in this paper relies on the expected value of export intensity, given a set of regressors. Thus, the general form of the estimated models is given by

$$
E\left(y_{i t} \mid x_{i t}\right)=x_{i t}^{\prime} \beta+u_{i t} \text {, }
$$

\footnotetext{
${ }^{3}$ For the dummy variable 'beneficiary', the output is the point-biserial correlation, due to the dichotomous nature of the variable.
} 
Table 4. Pairwise Pearson correlation matrix of explanatory variables

\begin{tabular}{|l|c|c|c|c|c|c|}
\hline & $(1)$ & $(2)$ & $(3)$ & $(4)$ & $(5)$ & $(6)$ \\
\hline Size (1) & 1.0000 & & & & & \\
\hline Age (2) & $0.2862^{\star * *}$ & 1.0000 & & & & \\
\hline Productivity (3) & $0.2240^{\star * *}$ & $0.0797^{\star * *}$ & 1.0000 & & & \\
\hline Debt Capacity (4) & $0.1149^{\star * *}$ & $0.0966^{\star * *}$ & $0.1733^{\star * *}$ & 1.0000 & & \\
\hline Beneficiary (5) & $0.1784^{\star * *}$ & $0.6005^{\star * *}$ & $0.2587^{\star * *}$ & $0.5092^{\star * *}$ & 1.0000 & \\
\hline Exports PT (6) & 0.0116 & 0.0411 & 0.0059 & 0.0012 & 0.0000 & 1.0000 \\
\hline
\end{tabular}

Note: ${ }^{\star * *},{ }^{\star *}$ and ${ }^{\star}$ denote significance at the $1 \%, 5 \%$ and $10 \%$ level, respectively.

where $y_{i t}$ is the export performance of firm $i$ in year $t$ and $x_{i t}^{\prime}$ is the matrix of the regressors. Unfolding this matrix, regarding the explanatory variables included, the main equation yields

$$
\begin{aligned}
& E\left(y_{i t} \mid x_{i t}\right)=\beta_{0}+\beta_{1} \text { Size }+\beta_{2} \text { Age }+\beta_{3} \text { Productivity }+\beta_{4} \text { DebtCapacity }+ \\
& \beta_{5} \text { Beneficiary }+\beta_{6} \text { Exports }_{P T}+u_{i t} .
\end{aligned}
$$

With regard to the application of the econometric methods detailed in the previous section, the equation was adapted in each model used, in accordance with the Eqs. (1), (8) and (12).

\subsection{Results}

Table 5 displays the estimation outputs for all the three models estimated, i.e., the two-step Heckman selection (Heckman, 1979), the fractional probit, following Papke and Wooldridge's (2008) non-linear panel data procedure, and the two-part model for fractional response variables, proposed by Ramalho et al. (2011).

Table 5. Results of the estimated models

\begin{tabular}{|l|c|c|c|}
\hline \multirow{2}{*}{ Variables } & \multicolumn{3}{|c|}{ Model } \\
\cline { 2 - 4 } & Two-step Heckman & Fractional Probit & Two-part Fractional Logit \\
\hline \multicolumn{3}{|c|}{ (Main equation) } \\
\hline \multirow{2}{*}{ Size } & $0.00022^{* *}$ & 0.00075 & 0.00074 \\
& $(0.00011)$ & $(0.00046)$ & $(0.00071)$ \\
\hline \multirow{2}{*}{ Age } & 0.00068 & 0.00065 & 0.00090 \\
& $(0.00064)$ & $(0.00211)$ & $(0.00337)$ \\
\hline \multirow{2}{*}{ Productivity } & $0.00476^{* *}$ & $0.00743^{* * *}$ & $0.01450^{* * *}$ \\
& $(0.00191)$ & $(0.00150)$ & $(0.00450)$ \\
\hline \multirow{2}{*}{ Debt Capacity } & $0.09407^{* *}$ & 0.53625 & 0.22205 \\
& $(0.05486)$ & $(0.09243)$ & $0.54714^{* * *}$ \\
\hline \multirow{2}{*}{ Beneficiary } & $0.28860^{* *}$ & $0.72588^{* * *}$ & $(0.16066)$ \\
\hline
\end{tabular}


End of Table 5

\begin{tabular}{|c|c|c|c|}
\hline \multirow{2}{*}{ Variables } & \multicolumn{3}{|c|}{ Model } \\
\hline & Two-step Heckman & Fractional Probit & Two-part Fractional Logit \\
\hline Exports PT & $\begin{array}{l}0.00002^{\star * *} \\
(3.81 \mathrm{e}-06)\end{array}$ & $\begin{array}{l}0.00004^{\star * \star} \\
(5.19 \mathrm{e}-06)\end{array}$ & $\begin{array}{l}0.00007^{* * *} \\
(0.00001)\end{array}$ \\
\hline Constant & $\begin{array}{l}-1.14020^{* * *} \\
(0.380245)\end{array}$ & $\begin{array}{c}-3.85664 * * * \\
(0.36114)\end{array}$ & $\begin{array}{l}-6.31739 * * * \\
(0.723671)\end{array}$ \\
\hline \multicolumn{4}{|c|}{ (Selection equation) } \\
\hline Size & $\begin{array}{c}0.00597 \\
(0.00269)\end{array}$ & $\mathrm{N}=1236$ & $\mathrm{~N}=737$ \\
\hline Age & $\begin{array}{l}0.00373 \\
(0.00269 \\
\end{array}$ & Wald: $C h i^{2}=177.60^{\star * *}$ & $\begin{array}{c}\text { Log-pseudolikelihood }= \\
-340.90002\end{array}$ \\
\hline Productivity & $\begin{array}{l}0.02111^{\star} \\
(0.11681)\end{array}$ & & $\mathrm{R}^{2}=0.10276$ \\
\hline Debt Capacity & $\begin{array}{l}0.24763^{* *} \\
(0.11187)\end{array}$ & & $\begin{array}{l}\text { Ramsay RESET (Lagrange- } \\
\text { Multiplier statistic) test: }\end{array}$ \\
\hline Beneficiary & $\begin{array}{c}1.38699^{* * *} \\
(0.18162)\end{array}$ & & $\mathrm{LM}(2)=0.114$ \\
\hline Exports PT & $\begin{array}{l}5.83 \mathrm{e}-06 \\
(0.00001)\end{array}$ & & $\mathrm{LM}(3)=0.131$ \\
\hline Net Profit & $\begin{array}{c}-2.97 \mathrm{e}-07^{* * *} \\
(9.93 \mathrm{e}-08)\end{array}$ & & $\begin{array}{l}\text { Goodness-of-fit link } \\
\text { (GOFF) tests }\end{array}$ \\
\hline \multirow[t]{5}{*}{ Constant } & $\begin{array}{l}-0.65486 \\
(0.92369)\end{array}$ & & GOFF1 $(\mathrm{LM})=0.100$ \\
\hline & & & GOFF2 $(\mathrm{LM})=0.118$ \\
\hline & $\begin{array}{c}\mathrm{N}=1236 \\
\text { (censored: } 499 \text { ) }\end{array}$ & & \\
\hline & $\begin{array}{c}\text { Wald: } C h i^{2}= \\
30.17^{* * *}\end{array}$ & & GOFF3 $(\mathrm{LM})=0.130$ \\
\hline & Lambda $=0.30812^{\star *}$ & & \\
\hline
\end{tabular}

Note: ${ }^{* *},{ }^{* *}$ and ${ }^{*}$ denote significance at the $1 \%, 5 \%$ and $10 \%$ level, respectively. Standard errors are presented in parentheses.

Regarding the estimation results, all three models produce similar results in terms of statistical significance and signal of the explanatory variables. The variables 'productivity', 'beneficiary' and 'exports PT' have positive and significant impact on the dependent variable, export performance. This consistency across the models signals the robustness of the results.

Good econometric practices recommend that when applying a two-step Heckman selection model, one must include at least one additional explanatory variable in the selection equation. Thus, net profit for the year was included. Regarding the results of the Heckman selection model, the lambda, $\lambda$, which is the product of the coefficient of correlation between the error terms of the main equation and selection equation, $\rho$, and the standard deviation of the error term in the main equation, $\sigma_{u}^{2}$, thus $\lambda=\rho \times \sigma_{u}^{2}$. In the two-step procedure, testing the significance of $\lambda=0$ is equivalent to testing for $\rho=0$ (Baum, 2006; Jones et al., 
2007). Considering this, the rejection of the null hypothesis of $\lambda=0$ indicates the presence of non-random selectivity, thus confirming sample selection bias within this sample. The presence of sample selection bias demonstrates that export intensity (continuous variable) should also reflect propensity (dichotomous variable), therefore should be jointly analysed. As described in section 3, the main drawback of the Heckman selection, however, is that it assumes a linear relationship between the explained and explanatory variables. In fact, through the computation of the linear predictions of $y_{i}$, it is shown that some predicted values lie outside the meaningful interval of $[0,1]$, namely 365 of the 1236 observations. Thus, despite the robustness in terms of overcoming sample selection bias, the mean values of $E\left(y_{i} \mid x_{i}\right)$ are influenced by this linear assumption and the magnitudes of the impacts of explanatory variables are undervalued.

The results of the panel data fractional probit, estimated through the QML method, reveal that this approach improves the individual significance and magnitude of the coefficients, except for variable size. Moreover, this model captures the effects of heterogeneity, revealing the importance of individual factors to the coefficient results. Despite the superior explanatory capacity, the fractional probit model does not solve the sample selection bias, previously identified and confirmed in the Heckman estimation. Therefore, a comparison of the models is not possible with a meaningful economic sense.

Thus, the two-part fractional response model arises as the most robust model, overcoming sample selection bias on the one hand, and ensuring the predicted values of $E\left(y_{i} \mid x_{i}\right)$ lie on the meaningful interval $[0,1]$ on the other. The robustness of the two-part fractional response model was assessed through the Ramsey RESET test (Lee et al., 1993; Ramalho et al., 2011). The results do not reject the null hypothesis, therefore confirming that the model is well specified. Additionally, the goodness-of-fit link tests (Ramalho et al., 2011, 2014) were performed. The results point to a no-rejection of the null hypothesis, i.e. confirming that there is no significant difference between the observed and the expected values.

In summary, despite the similarities of the results of the three estimated models, the twopart fractional regression model arises as the one that best fits the study of export performance of Portuguese wine firms, overcoming the drawbacks of both the Heckman selection model and of the fractional probit.

The comparison of the coefficients among the three models is not economically meaningful, due to the methodological differences to estimate the coefficients of each model. The comparison is only meaningful when comparing the average MEs of each regressor in the dependent variable. Therefore, the average MEs were computed, following the Eqs. (13), (14), (15) and (16), and are displayed in Table 6.

Table 6. Average marginal effects

\begin{tabular}{|l|c|c|c|}
\hline \multirow{2}{*}{ Variables } & \multicolumn{3}{|c|}{ Model } \\
\cline { 2 - 4 } & Two-step Heckman & Fractional Probit & Two-part Fractional Logit \\
\hline \multirow{2}{*}{ Size } & $0.00022^{* *}$ & $0.00566^{\star}$ & $0.00015^{\star}$ \\
& $(0.00012)$ & $(0.00330)$ & $(0.00009)$ \\
\hline \multirow{2}{*}{ Age } & 0.00068 & 0.00351 & 0.00018 \\
& $(0.00064)$ & $(0.01163)$ & $(0.00043)$ \\
\hline
\end{tabular}


End of Table 6

\begin{tabular}{|c|c|c|c|}
\hline \multirow{2}{*}{ Variables } & \multicolumn{3}{|c|}{ Model } \\
\hline & Two-step Heckman & Fractional Probit & Two-part Fractional Logit \\
\hline Productivity & $\begin{array}{c}0.00476^{* * *} \\
(0.00158)\end{array}$ & $\begin{array}{c}0.00670^{* * *} \\
(0.00125)\end{array}$ & $\begin{array}{c}0.00293^{* * *} \\
(0.00065)\end{array}$ \\
\hline Debt Capacity & $\begin{array}{c}0.09407^{\star *} \\
(0.04383)\end{array}$ & $\begin{array}{c}0.00836 \\
(0.01472)\end{array}$ & $\begin{array}{c}0.04490 \\
(0.03465)\end{array}$ \\
\hline Beneficiary & $\begin{array}{c}0.28860 * * * \\
(0.08596)\end{array}$ & $\begin{array}{c}0.04740^{* * *} \\
(0.00747)\end{array}$ & $\begin{array}{c}0.11062^{* * *} \\
(0.20867)\end{array}$ \\
\hline Exports PT & $\begin{array}{c}0.00002^{\star * *} \\
(3.87 \mathrm{e}-06)\end{array}$ & $\begin{array}{c}0.65692^{* * *} \\
(0.93032)\end{array}$ & $\begin{array}{l}0.00002^{* * *} \\
(3.21 \mathrm{e}-06)\end{array}$ \\
\hline
\end{tabular}

Note: ${ }^{* *},{ }^{* *}$ and ${ }^{*}$ denote significance at the $1 \%, 5 \%$ and $10 \%$ level, respectively. Standard errors are presented in parentheses.

The magnitudes of the average marginal effects illustrate how the explanatory variables influence the expected value of export performance. Thus, despite the differences in the magnitudes across each model, it is noticeable that the variables 'size, 'productivity', 'beneficiary' and 'exports PT' are positive determinants of export performance, whereas the positive impact of 'debt capacity' is only significant in the Heckman selection model and the fractional probit model. 'Age' is not significant in any model, reinforcing the contentious results in the literature.

Regarding the RBV perspective, all three models identified 'size' and 'productivity' as positive determinants of export performance. The positive relationship between size and export performance demonstrates that larger firms have more available resources to compete in external markets than small firms. Larger firms also have higher recognition and market power, which can lead to competitive advantage in the internationalization process. These results corroborate the majority of the existing literature, where firm size is also usually identified as a positive driver of export performance (Krammer et al., 2018; Lee et al., 2009; LiPuma et al., 2013; Lu et al., 2009; Singh, 2009). Despite the relevance of experience, the effects of firm age are yet to be consensual in the literature, and in all models estimated, firm age has no significant effect on export performance. Concerning labour productivity, the results confirm the existing literature that links skilled workers and advanced training to higher rates of export performance (Lopez-Rodriguez et al., 2018; Munch \& Schaur, 2018). These results show that human resources are crucial to product quality and improvements in market power, thus higher productivity leads to a better export performance.

In terms of the IBV perspective, the marginal effects show a positive link between government funding and export performance, in line with Munch and Schaur (2018). The results demonstrate that such programmes incentivize export activities and support firms in reaching external markets. These positive links also illustrate the moderating effects that institutional forces may have regarding firms' export performance, well established in the literature (LiPuma et al., 2013; Lu et al., 2009; Munch \& Schaur, 2018).

Summarizing, both internal resources and external environment are drivers of firms' export performance. Internal resources may help firms to develop their internationalization 
strategies, as well as determine their competitiveness in terms of costs, selling-quantities and product placement. On the other hand, a well-established institutional collaboration may induce export performance, i.e. the institutional environment acts as a moderator between firms and external markets.

\section{Conclusions}

Firms' export performance remains a challenging field of research, since there is no consensus on how to measure firm export behaviour or the econometric approaches that accurately fit the issue. Given this context, the main goal of this paper is to contribute to a better understanding of export performance, using up-to-date microeconometric approaches to provide robust insights. Specifically, based on data from a panel of Portuguese wine firms, export performance is modelled combining the RBV with the IBV, considering the strategic decisions and therefore the fractional nature of the dependent variable, which leads to the estimation of three models: (i) a two-step Heckman selection model; (ii) a fractional probit model; and (iii) a two-part fractional response model, analysing the pros and cons of each approach and comparing the results.

The three models show similar results concerning statistical significance and signal as well as the magnitude of the average marginal effects, which highlight the robustness of the results. However, disparities in the magnitudes are identified and analysed. Considering the strategic decisions associated with export performance, the Heckman selection model overcomes sample selection bias through the inclusion of the inverse Mills' ratio in the interest equation. However, this approach produces predictions outside the meaningful interval of $[0,1]$. The fractional probit, as a non-linear approach, offers superior explanatory capacity, but fails to solve sample selectivity issues. The two-part fractional response model arises as the most robust estimation, overcoming selection bias by estimating separately the binary and the continuous components on the one hand, and accounting for the fractional response nature of the dependent variable through non-linear estimations, on the other.

Regardless of the econometric method used, the results show that firm size, measured as firms' total turnover, and labour productivity are both positive internal drivers of export performance. On the other hand, the moderating effect of institutional environment is confirmed through the positive and strong effect of the public programmes towards promotion in third countries.

Summing up, the findings in this paper corroborate the main conclusions in the existing literature, regarding the combination effects of both RBV and IBV. On the one hand, firms' internal resources drive their capacity to promote and execute strategies with success. On the other hand, the institutional environment steers operating firms into new or different strategies.

This paper is not without limitations. For instance, future research could focus on the developing of sample selection models for fractional response variables, in line with the research of Schwiebert (2016), who is developing the new Heckman fractional model (Heckfrac). Moreover, future research can break through in terms of analysing the effects of neglected individual heterogeneity. 


\section{Acknowledgements}

This work is supported by the project NORTE-01-0145-FEDER-000038 (INNOVINE \& WINE - Innovation Platform of Vine \& Wine) and by European and Structural and Investment Funds in the FEDER component, through the Operational Competitiveness and Internationalization Program (COMPETE 2020) [Project No. 006971 UIC/SOC/04011)]; and national funds, through the FCT - Portuguese Foundation for Science and Technology under the UID/SOC/04011/2013.

\section{Author contributions}

JR and SG conceived the study theoretically. SF and JR choose the econometric methods to be used. SF was responsible for the development of data and econometric analysis. SF wrote the first draft of the article. SF, JR and SG together are responsible for the final draft of the article.

\section{Disclosure statement}

The authors declare no conflict of interests, financial or otherwise.

\section{References}

Antonietti, R., \& Marzucchi, A. (2014). Green tangible investment strategies and export performance: A firm-level investigation. Ecological Economics, 108, 150-161. https://doi.org/10.1016/j.ecolecon.2014.10.017

Anwar, S., \& Nguyen, L. P. (2011). Foreign direct investment and export spillovers: Evidence from Vietnam. International Business Review, 20(2), 177-193. https://doi.org/10.1016/j.ibusrev.2010.11.002

Barney, J. B. (1991). Firm resources and sustained competitive advantage. Journal of Management, 17(1). https://doi.org/10.1177/014920639101700108

Barney, J., Wright, M., \& Ketchen, D. J. (2001). The resource-based view of the firm: Ten years after 1991. Journal of Management, 27(6), 625-641. https://doi.org/10.1016/S0149-2063(01)00114-3

Baum, C. F. (2006). An introduction to modern econometrics using Stata. STATA Press.

Behmiri, N. B., Rebelo, J. F., Gouveia, S., \& António, P. (2019). Firm characteristics and export performance in Portuguese wine firms. International Journal of Wine Business Research, 31(3), 419-440. https://doi.org/10.1108/IJWBR-07-2018-0032

Brakman, S., Garretsen, H., van Maarseveen, R., \& Zwaneveld, P. (2019). Firm heterogeneity and exports in the Netherlands: Identifying export potential beyond firm productivity. The Journal of International Trade \& Economic Development, 29(1), 36-68. https://doi.org/10.1080/09638199.2019.1631876

Burgman, T. A. (1996). An empirical examination of multinational corporate capital structure. Journal of International Business Studies, 27(3), 553-570. https://doi.org/10.1057/palgrave.jibs.8490143

Chen, J., Sousa, C. M. P., \& He, X. (2016). The determinants of export performance: a review of the literature 2006-2014. International Marketing Review, 33(5), 626-670. https://doi.org/10.1108/IMR-10-2015-0212 
D’Aspremont, C., Dos Santos Ferreira, R., \& Gérard-Varet, L. A. (1996). On the Dixit-Stiglitz model of monopolistic competition. American Economic Review, 86(3), 623-629.

European Commission. (2014). Helping firms grow. European Competitiveness Report 2014 (Commission Staff Working Document SWD (2014) 277 final). European Union, Brussels. https://doi.org/10.2769/28020

De Falco, S. E., \& Simoni, M. (2014). The effect of public export incentives on Italian textile and fashion SMEs. International Studies of Management and Organization, 44(1), 70-83. https://doi.org/10.2753/IMO0020-8825440105

Delen, D., Kuzey, C., \& Uyar, A. (2013). Measuring firm performance using financial ratios: A decision tree approach. Expert Systems with Applications, 40(10), 3970-3983. https://doi.org/10.1016/j.eswa.2013.01.012

Fan, H., Lai, E. L., \& Qi, H. (2019). Trade liberalization and Firms' Export performance in China: Theory and evidence. Journal of Comparative Economics, 47(3), 640-648. https://doi.org/10.1016/j.jce.2019.05.001

Fernández, Z., \& Nieto, M. J. (2006). Impact of ownership on the international involvement of SMEs. Journal of International Business Studies, 37(3), 340-351. https://doi.org/10.1057/palgrave.jibs.8400196

Ganotakis, P., \& Love, J. H. (2012). Export propensity, export intensity and firm performance: The role of the entrepreneurial founding team. Journal of International Business Studies, 43, 693-718. https://doi.org/10.1057/jibs.2012.16

Gonenc, H., \& de Haan, D. J. (2014). Firm internationalization and capital structure in developing countries: The role of financial development. Emerging Markets Finance and Trade, 50(2), 169-189. https://doi.org/10.2753/REE1540-496X500210

Hammervoll, T., Mora, P., \& Toften, K. (2014). The financial crisis and the wine industry: The performance of niche firms versus mass-market firms. Wine Economics and Policy, 3(2), 108-114. https://doi.org/10.1016/j.wep.2014.11.001

Harrigan, K. R. (1983). Research methodologies for contingency approaches to business strategy. Academy of Management Review, 8(3). https://doi.org/10.5465/amr.1983.4284376

Heckman, J. J. (1979). Sample selection bias as a specification error. Econometrica, 47(1), 153. https://doi.org/10.2307/1912352

Helfat, C. E., \& Peteraf, M. A. (2003). The dynamic resource-based view: Capability lifecycles. Strategic Management Journal, 24(10), 997-1010. https://doi.org/10.1002/smj.332

Hultman, M., Katsikeas, C. S., \& Robson, M. J. (2011). Export promotion strategy and performance: The role of international experience. Journal of International Marketing, 19(4), 17-39. https://doi.org/10.1509/jimk.19.4.17

Jones, A. M., Rice, N., Bago d'Uva, T., \& Balia, S. (2007). Applied health economics ( $1^{\text {st }}$ ed.). Routledge. https://doi.org/10.4324/9780203972304

Krammer, S. M. S., Strange, R., \& Lashitew, A. (2018). The export performance of emerging economy firms: The influence of firm capabilities and institutional environments. International Business Review, 27(1), 218-230. https://doi.org/10.1016/j.ibusrev.2017.07.003

Le, T. P. V., \& Phan, T. B. N. (2017). Capital structure and firm performance: Empirical evidence from a small transition country. Research in International Business and Finance, 42(June), 710-726. https://doi.org/10.1016/j.ribaf.2017.07.012

Lee, S. H., Beamish, P. W., Lee, H. U., \& Park, J. H. (2009). Strategic choice during economic crisis: Domestic market position, organizational capabilities and export flexibility. Journal of World Business, 44(1), 1-15. https://doi.org/10.1016/j.jwb.2008.03.015 
Lee, T. H., White, H., \& Granger, C. W. J. (1993). Testing for neglected nonlinearity in time series models. A comparison of neural network methods and alternative tests. Journal of Econometrics, 56(3), 269-290. https://doi.org/10.1016/0304-4076(93)90122-L

Leonidou, L. C. (2004). An analysis of the barriers hindering small business export development. Journal of Small Business Management, 42(3), 279-302. https://doi.org/10.1111/j.1540-627X.2004.00112.x

LiPuma, J. A., Newbert, S. L., \& Doh, J. P. (2013). The effect of institutional quality on firm export performance in emerging economies: A contingency model of firm age and size. Small Business Economics, 40(4), 817-841. https://doi.org/10.1007/s11187-011-9395-7

Lopez-Rodriguez, J., Calvo Dopico, D., \& Del Castillo Puente, A. M. (2018). Export performance in Spanish wineries: the role of human capital and quality management system. European Journal of International Management, 12(3), 311-333. https://doi.org/10.1504/EJIM.2018.10011273

Lorenzo, J. R. F., Rubio, M. T. M., \& Garcés, S. A. (2018). The competitive advantage in business, capabilities and strategy. What general performance factors are found in the Spanish wine industry? Wine Economics and Policy, 7(2), 94-108. https://doi.org/10.1016/j.wep.2018.04.001

Lu, J., Xu, B., \& Liu, X. (2009). The effects of corporate governance and institutional environments on export behaviour in emerging economies evidence from China. Management International Review, 49(4), 455-478. https://doi.org/10.1007/s11575-009-0004-9

Mais, I., \& Amal, M. (2011). Determinants of export performance: An institutional approach. Latin American Business Review, 12(4), 281-307. https://doi.org/10.1080/10978526.2011.633029

Malca, O., Peña-Vinces, J., \& Acedo, F. (2019). Export promotion programmes as export performance catalysts for SMEs: Insights from an emerging economy. Small Business Economics. https://doi.org/10.1007/s11187-019-00185-2

Maurel, C. (2009). Determinants of export performance in French wine SMEs. International Journal of Wine Business Research, 21(2), 118-142. https://doi.org/10.1108/17511060910967971

Menghini, S. (2015). The new market challenges and the strategies of the wine companies. Wine Economics and Policy, 4(2), 75-77. https://doi.org/10.1016/j.wep.2015.11.003

Munch, J., \& Schaur, G. (2018). the effect of export promotion on firm-level performance. American Economic Journal: Economic Policy, 10(1), 357-387. https://doi.org/10.1257/pol.20150410

Nam, J., Liu, X., Lioliou, E., \& Jeong, M. (2018). Do board directors affect the export propensity and export performance of Korean firms? A resource dependence perspective. International Business Review, 27(1), 269-280. https://doi.org/10.1016/j.ibusrev.2017.08.001

Onkelinx, J., Manolova, T. S., \& Edelman, L. F. (2016). The human factor: Investments in employee human capital, productivity, and SME internationalization. Journal of International Management, 22(4), 351-364. https://doi.org/10.1016/j.intman.2016.05.002

Papke, L. E., \& Wooldridge, J. M. (1996). Econometric methods for fractional response variables with an application to 401(k) plan participation rates. Journal of Applied Econometrics, 11(6), 619-632. https://doi.org/10.1002/(SICI)1099-1255(199611)11:6<619::AID-JAE418>3.0.CO;2-1

Papke, L. E., \& Wooldridge, J. M. (2008). Panel data methods for fractional response variables with an application to test pass rates. Journal of Econometrics, 145(1-2), 121-133. https://doi.org/10.1016/j.jeconom.2008.05.009

Parenti, M., Ushchev, P., \& Thisse, J. F. (2017). Toward a theory of monopolistic competition. Journal of Economic Theory, 167, 86-115. https://doi.org/10.1016/j.jet.2016.10.005

Paul, J., Parthasarathy, S., \& Gupta, P. (2017). Exporting challenges of SMEs: A review and future research agenda. Journal of World Business, 52(3), 327-342. https://doi.org/10.1016/j.jwb.2017.01.003

Peng, M. W., Wang, D. Y. L., \& Jiang, Y. (2008). An institution-based view of international business strategy: A focus on emerging economies. Journal of International Business Studies, 39, 920-936. https://doi.org/10.1057/palgrave.jibs.8400377 
Ramalho, E. A., Ramalho, J. J. S., \& Murteira, J. M. R. (2011). Alternative estimating and testing empirical strategies for fractional regression models. Journal of Economic Surveys, 25(1), 19-68. https://doi.org/10.1111/j.1467-6419.2009.00602.x

Ramalho, E. A., Ramalho, J. J. S., \& Murteira, J. M. R. (2014). A generalized goodness-of-functional form test for binary and fractional regression models. Manchester School. https://doi.org/10.1111/manc.12032

Robertson, C., \& Chetty, S. K. (2000). A contingency-based approach to understanding export performance. International Business Review, 9(2), 211-235. https://doi.org/10.1016/S0969-5931(99)00037-2

Saha, A., Capps, O., \& Byrne, P. J. (1997). Calculating marginal effects in dichotomous - continuous models. Applied Economics Letters, 4(3), 181-185. https://doi.org/10.1080/135048597355474

Santos-Vijande, M. L., López-Sánchez, J. Á., \& Trespalacios, J. A. (2012). How organizational learning affects a firm's flexibility, competitive strategy, and performance. Journal of Business Research, 65(8), 1079-1089. https://doi.org/10.1016/j.jbusres.2011.09.002

Schwiebert, J. (2016). A sample selection model for fractional response variables. In Annual Conference 2016 (Augsburg): Demographic Change (No. 145527). Verein für Socialpolitik/German Economic Association.

Singh, D. A. (2009). Export performance of emerging market firms. International Business Review, 18(4), 321-330. https://doi.org/10.1016/j.ibusrev.2009.03.002

Sousa, C. M. P., Martínez-López, F. J., \& Coelho, F. (2008). The determinants of export performance: A review of the research in the literature between 1998 and 2005. International Journal of Management Reviews, 10(4), 343-374. https://doi.org/10.1111/j.1468-2370.2008.00232.x

Wang, X., Chen, A., Wang, H., \& Li, S. (2017). Effect of export promotion programs on export performance: Evidence from manufacturing SMEs. Journal of Business Economics and Management, 18(1), 131-145. https://doi.org/10.3846/16111699.2016.1278031

Wang, Y., Cao, W., Zhou, Z., \& Ning, L. (2013). Does external technology acquisition determine export performance? Evidence from Chinese manufacturing firms. International Business Review, 22(6), 1079-1091. https://doi.org/10.1016/j.ibusrev.2013.02.009

Wernerfelt, B. (1984). A resource-based view of the firm. Strategic Management Journal, 5(2), 171-180. https://doi.org/10.1002/smj.4250050207

Yi, J., Wang, C., \& Kafouros, M. (2013). The effects of innovative capabilities on exporting: Do institutional forces matter? International Business Review, 22(2), 392-406.

https://doi.org/10.1016/j.ibusrev.2012.05.006 


\section{APPENDIX}

Table A1. Firms' export performance: an empirical literature summary

\begin{tabular}{|c|c|c|c|c|c|}
\hline Authors & Theory & $\begin{array}{c}\text { Dependent } \\
\text { Variable }\end{array}$ & $\begin{array}{l}\text { Explanatory } \\
\text { Variables }\end{array}$ & Method & Conclusions \\
\hline $\begin{array}{l}\text { Fernandez } \\
\text { and Nieto } \\
(2006)\end{array}$ & RBV & $\begin{array}{l}\text { Export } \\
\text { Propensity; } \\
\text { Export Intensity }\end{array}$ & $\begin{array}{l}\text { Family ownership } \\
\text { dummy; } \\
\text { Corporate } \\
\text { blockholder dummy; } \\
\text { Firm age; } \\
\text { Firm size; } \\
\text { Alliances dummy; } \\
\text { Innovation ratio }\end{array}$ & $\begin{array}{l}\text { Probit } \\
\text { Model; } \\
\text { Tobit Model }\end{array}$ & $\begin{array}{l}\text { Alliances, } \\
\text { innovation, age and } \\
\text { size are positive } \\
\text { drivers of export } \\
\text { performance; } \\
\text { Corporate } \\
\text { blockholders are } \\
\text { positively associated } \\
\text { with export } \\
\text { intensity. }\end{array}$ \\
\hline $\begin{array}{l}\text { Lee et al. } \\
\text { (2009) }\end{array}$ & RBV & Export intensity & $\begin{array}{l}\text { Domestic market } \\
\text { position; } \\
\text { Innovation (R\&D } \\
\text { expenditures); } \\
\text { Advertising } \\
\text { expenditures; } \\
\text { Firm size; } \\
\text { Economic } \\
\text { performance; } \\
\text { FDI; } \\
\text { Post-crisis dummy }\end{array}$ & $\begin{array}{l}\text { Generalized } \\
\text { least squares } \\
\text { (GLS) } \\
\text { regression }\end{array}$ & $\begin{array}{l}\text { Domestic market } \\
\text { position is positive } \\
\text { driver of export } \\
\text { performance; } \\
\text { R\&D is positive } \\
\text { driver and } \\
\text { advertising negative; } \\
\text { Firm size is } \\
\text { positively associated } \\
\text { with export } \\
\text { performance; } \\
\text { FDI becomes } \\
\text { positive driver in } \\
\text { post-crisis period. }\end{array}$ \\
\hline $\begin{array}{l}\text { Lu et al. } \\
\text { (2009) }\end{array}$ & IBV & Export intensity & $\begin{array}{l}\text { Private shareholding; } \\
\text { Foreign } \\
\text { shareholding; } \\
\text { Institutional } \\
\text { Environment Index; } \\
\text { Return on sales; } \\
\text { Capital labour ratio; } \\
\text { Firm size; } \\
\text { Firm age }\end{array}$ & $\begin{array}{l}\text { Tobit } \\
\text { Model; } \\
\text { Generalized } \\
\text { method-of- } \\
\text { moments } \\
\text { (GMM- } \\
\text { system) }\end{array}$ & $\begin{array}{l}\text { Institutional } \\
\text { environment } \\
\text { positively moderates } \\
\text { export strategic } \\
\text { decisions; } \\
\text { Firm age and firm } \\
\text { size positively } \\
\text { influences export } \\
\text { performance. }\end{array}$ \\
\hline Singh (2009) & RBV & Export intensity & $\begin{array}{l}\text { Firm size; } \\
\text { Firm age; } \\
\text { R\&D expenditures; } \\
\text { Advertising } \\
\text { expenditures; } \\
\text { Group affiliation; } \\
\text { Exchange rate; } \\
\text { World GDP }\end{array}$ & $\begin{array}{l}\text { Generalized } \\
\text { two-stages } \\
\text { least squares } \\
\text { (G2SLS) } \\
\text { regression }\end{array}$ & $\begin{array}{l}\text { Firm size, R\&D } \\
\text { expenditures and } \\
\text { world GDP are } \\
\text { positive drivers of } \\
\text { export performance; } \\
\text { Firm age, } \\
\text { advertising } \\
\text { expenditures and } \\
\text { exchange rate } \\
\text { negatively influences } \\
\text { export performance. }\end{array}$ \\
\hline
\end{tabular}


Continued Table A1

\begin{tabular}{|c|c|c|c|c|c|}
\hline Authors & Theory & $\begin{array}{c}\text { Dependent } \\
\text { Variable }\end{array}$ & $\begin{array}{l}\text { Explanatory } \\
\text { Variables }\end{array}$ & Method & Conclusions \\
\hline $\begin{array}{l}\text { Yi et al. } \\
\text { (2013) }\end{array}$ & $\begin{array}{l}\text { RBV, } \\
\text { IBV }\end{array}$ & Export intensity & $\begin{array}{l}\text { Innovative } \\
\text { capabilities; } \\
\text { Foreign ownership; } \\
\text { Government } \\
\text { relationship; } \\
\text { Business group } \\
\text { affiliation; } \\
\text { Marketization; } \\
\text { Firm size; } \\
\text { Firm age }\end{array}$ & \begin{tabular}{|l|} 
Hierarchical \\
moderated \\
regression; \\
GMM
\end{tabular} & $\begin{array}{l}\text { Innovative } \\
\text { capabilities, foreign } \\
\text { ownership and firm } \\
\text { size are positively } \\
\text { related with export } \\
\text { performance; } \\
\text { Firm age and } \\
\text { government } \\
\text { relationship are } \\
\text { negatively associated } \\
\text { with export } \\
\text { performance. }\end{array}$ \\
\hline $\begin{array}{l}\text { LiPuma } \\
\text { et al. (2013) }\end{array}$ & IBV & Export intensity & $\begin{array}{l}\text { Institutional quality } \\
\text { (World Business } \\
\text { Environment } \\
\text { Survey); } \\
\text { Firm age; } \\
\text { Firm size; } \\
\text { Industry dummies }\end{array}$ & $\begin{array}{l}\text { Heckman } \\
\text { selection } \\
\text { model }\end{array}$ & $\begin{array}{l}\text { Higher-quality } \\
\text { institutions are } \\
\text { positively related to } \\
\text { export performance; } \\
\text { Firm size enhances } \\
\text { export performance }\end{array}$ \\
\hline $\begin{array}{l}\text { Wang et al. } \\
(2013)\end{array}$ & $\begin{array}{l}\text { RBV, } \\
\text { IBV }\end{array}$ & Export intensity & $\begin{array}{l}\text { Technological } \\
\text { strength; } \\
\text { Foreign technology } \\
\text { acquisition; } \\
\text { Innovation; } \\
\text { Total assets; } \\
\text { Firm age; } \\
\text { Firm size; } \\
\text { R\&D intensity } \\
\end{array}$ & Tobit model & $\begin{array}{l}\text { External and } \\
\text { foreign technology } \\
\text { acquisition is } \\
\text { positively associated } \\
\text { with export } \\
\text { performance; } \\
\text { Firm size and R\&D } \\
\text { intensity boost } \\
\text { export performance. }\end{array}$ \\
\hline $\begin{array}{l}\text { Krammer } \\
\text { et al. (2017) }\end{array}$ & $\begin{array}{l}\text { RBV, } \\
\text { IBV }\end{array}$ & Export intensity & $\begin{array}{l}\text { Political stability } \\
\text { index; } \\
\text { Corruption index; } \\
\text { Skilled workers; } \\
\text { Management } \\
\text { experience; } \\
\text { Foreign ownership; } \\
\text { Public ownership; } \\
\text { Firm size; } \\
\text { Firm age }\end{array}$ & $\begin{array}{l}\text { Heckman } \\
\text { selection } \\
\text { model }\end{array}$ & $\begin{array}{l}\text { Political stability } \\
\text { and foreign } \\
\text { ownership are } \\
\text { positively related to } \\
\text { export performance; } \\
\text { Firm size and firm } \\
\text { age enhance export } \\
\text { performance; } \\
\text { Public ownership } \\
\text { stunts export } \\
\text { performance. }\end{array}$ \\
\hline $\begin{array}{l}\text { Munch } \\
\text { and Schaur } \\
(2018)\end{array}$ & $\begin{array}{l}\text { RBV, } \\
\text { IBV }\end{array}$ & $\begin{array}{l}\begin{array}{l}\text { Export } \\
\text { propensity }\end{array} \\
\text { Total sales }\end{array}$ & $\begin{array}{l}\text { Firm size; } \\
\text { Skilled workers; } \\
\text { Productivity; } \\
\text { Total sales; } \\
\text { Export promotion } \\
\text { activities }\end{array}$ & $\begin{array}{l}\text { Probit } \\
\text { model; } \\
\text { FE model }\end{array}$ & $\begin{array}{l}\text { Export promotion } \\
\text { improves small- } \\
\text { firms' total sales, } \\
\text { value added and } \\
\text { productivity. }\end{array}$ \\
\hline
\end{tabular}


End of Table A1

\begin{tabular}{|l|l|l|l|l|l|}
\hline \multicolumn{1}{|c|}{ Authors } & Theory & \multicolumn{1}{c|}{$\begin{array}{c}\text { Dependent } \\
\text { Variable }\end{array}$} & \multicolumn{1}{|c|}{$\begin{array}{c}\text { Explanatory } \\
\text { Variables }\end{array}$} & Method & \multicolumn{1}{c|}{ Conclusions } \\
\hline $\begin{array}{l}\text { Lopez- } \\
\text { Rodriguez } \\
\text { et al. (2018) }\end{array}$ & RBV & Export intensity & $\begin{array}{l}\text { Skilled workers; } \\
\text { Advanced training; } \\
\text { Quality management } \\
\text { system dummy; } \\
\text { Firm size; } \\
\text { Firm age }\end{array}$ & Tobit model & $\begin{array}{l}\text { Advanced training } \\
\text { improves export } \\
\text { performance; } \\
\text { Firm age is } \\
\text { positively related } \\
\text { with export } \\
\text { performance, as } \\
\text { well as having a } \\
\text { quality management } \\
\text { system. }\end{array}$ \\
\hline $\begin{array}{l}\text { Behmiri } \\
\text { et al. (2019) }\end{array}$ & RBV & $\begin{array}{l}\text { Export } \\
\text { propensity } \\
\text { Export intensity }\end{array}$ & $\begin{array}{l}\text { Firm size } \\
\text { Firm age } \\
\text { Productivity } \\
\text { Efficiency }\end{array}$ & $\begin{array}{l}\text { Firm size is } \\
\text { positively related } \\
\text { with export } \\
\text { performance; } \\
\text { Older firms are less } \\
\text { likely to engage in } \\
\text { export activities; } \\
\text { Efficiency does } \\
\text { not impact export } \\
\text { performance. }\end{array}$ \\
\hline
\end{tabular}

